\title{
From the Difficulties of the City to the Happiness of Cosmopolis
}

\section{Roman Kljujkov* and Sergey Kljujkov}

Department of Environmental Science, Mariupol, Ukraine

*Corresponding Author: Roman Kljujkov, Department of Environmental Science, Mariupol, Ukraine

Received: April 08,2019; Published: June 11, 2019

DOI: 10.31080/ASAG.2019.03.0521

The people always took care of life together. Live in prosperity, happiness and peace with everyone is everyone's dream. And it does not go away with the years. How to organize such a life?

The solution to this problem, submitted at the conference, is already contained in the formulation her by the words: "good, virtue, blessing, well-being, habits, behavior, ethics, friendship, peace, happiness". The deep concepts of these words together were successfully implemented in the VIII century BC in ancient Greece, where people always sought to live in prosperity, happiness and

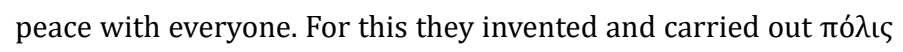
- a special custom and practice of the non-conflict organization of the social, economic, political, cultural and religious life of a group of people with different views and wealth status, religion, habits and moods.

Heraclitus (535-475 BC) in the treatise "On Nature" by comparing human and divine laws, perfected this popular Greek

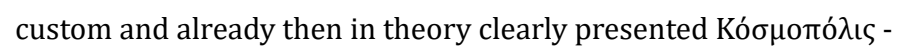
the Ecumenical Community of people and Gods.

Over time, the ancient Greek knowledge and experience became available to the whole world. The considered custom has taken root among many peoples, spread to large territories (cities, states, regions, continents) - worldwide, and today he appears as globalization (for the first time this English term was fixed in 1961).

Was Something useful, true, eternal in the custom, which for the first time the elaborated and reasonably comprehended in ancient Greece, and for millennia successfully tested by the peoples of the whole world?

Let's try to understand him. For this, it is necessary to return to History and carefully study the legacy of Heraclitus, Pythagoras, Socrates and Plato, "those who heed the universal Logos", rejecting the teachings of all the others - "uncomprehending" (according to Heraclitus).

In her book (fr. 130B104), Heraclitus criticized that it is not necessary to establish the human laws of life "without a mind", asserted the primacy of the "One" over "many".

He taught how to "with a mind" rely on the Universal Logos (fr.131B114): "Those who wish to speak wisely must rely firmly

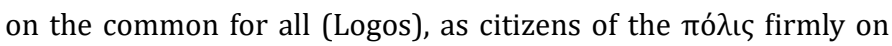
the law, and even much harder, for all human laws depend, as from the breadwinner, from one - the Divine. He dominates unlimitedly according to his will, and he is the one who dominates all (human laws) and overcomes all them".

He taught, if you establish laws, you with Arrogance do not need to invent human "true" axioms, but need to consciously build on basing on the unassailable all-powerful eternal Divine Laws that

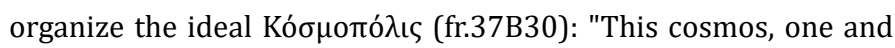
the same for all, was created by none of the gods, none of the people, but it has always been, is and will be an ever living fire, flashing and diminishing in size". In Space there are no separate states - there is the One Empire of Zeus: "mortal people" and "immortal Gods". People should strive to Unity with the Gods, to repeat the Divine Laws in the construction of their states.

Thus, Heraclitus the treatise wrote not about Nature, but about the ideal state building! Plato also used this method and left us with the dialogues "State", "Laws" and all the rest. But not about ideal state building and laws, but about the ideal mathematical model of Chora and its model ideals, by coding them as "mobile" and "reasonable" numbers!

Plato, further developing the Divine Knowledge of Heraclitus, Pythagoras and Socrates, discovered the fundamental property of Nature - the omnipresent reasonableness that provides a rational 
Device and a reasonable Cognition of the world. Reasonableness samples create only 16 qualitative actual infinities, necessarily having a limit, "end point", since they end eternally with the ideals of Plato. They arethe Parts of the World Mind of God and the criteria of the Absolute Truth ("Light of Life" in the cabbala and the Bible). Among the millions of boundless potential infinities of Aristotle and innumerable reasonableness of the human mind, only 16 topmost actual infinities of Plato by their exclusive ordersqualities weave the entire Divine world - as "the One" of Heraclitus.

Plato brilliantly completed the God-likeness proposed by Heraclitus!

Plato sharply divided Cognition into understanding and mind. Known axiomatic method of understanding operated only with "quantitative relations and spatial forms of the real world" (Engels) and provided only the most primitive understanding «quantity» easily accessible for any potential and actual infinity. In the same time created by Plato an unknown unique sensible method with the help only of many actual infinity mathematically described all other reasonable orders and qualities of the world discovered by Plato.

By the God-likeness copying of only 16 "reasonable" ideals Plato was able to freely, mathematically accurately and easily unite the obvious authenticity of the empirical method with the logical consistency of the rational method and even with the indisputable Truth. As soon as the arbitrary elements of Nature unite in aggregate by any Plato's ideal, within the limits of his part of World God's Mind, spontaneously from nowhere, a new wisdom comes as the Miracle of Plato! And Truth of this aggregate is revealed! This is recognized as a "quintessence", "ether", "inspiration", "revelation", "energy of Qi", intuition and many other things than Mankind has been using for a long time, without understanding - whence is all this, who is its true host?

Plato by "Dialogs" encrypted "the only correct way" to the 16 ideals of the World Mind of God and repeatedly demonstrated the miraculous manifestation of ideals by the unique mystical Miracle of Plato in an ideal mathematical model Chora. Chora - is the only Mediator between the real and ideal worlds, available to Mankind, but most thoroughly and permanently encoded by the "Soul, Eroth, State" and other mystifications of cabbala.

Cabbala is a secret Teaching. Its history is always kept out of hand, but she wants to open himself, she bestows the Divine "Light of life".
Plato made the mathematical cabbala and customize it Cognition in the direction of "God for Man" - theocentrism. Aristotle changed the direction "oppositely" "Man for God" - anthropocentrism. In this - the main source of selfishness, "darkness of death", sin, split, evil, Injustice and the wars of Humanity.

There are two mutually contrary statements ("Cabbala was the source of identical constructions in Greek philosophy" and "Greek philosophical knowledge was borrowed by cabbalistic tradition") or, was it one, but twofold expression?

The great "coarse truth," the true hidden motive of those interrelated historical events is that cabbala is the oldest and earliest wisdom that tells on complex, many structured Order of the all in the world that aims at one goal. From times immemorial, cabbala knowledge once emerging, was transmitted secretly, by means of encoded (always not quite clear) mystics, magic, prayer from generation to generation. It was mathematically clear set out in Plato's writing (encoded as well) in "theory of ideas", numerical dialectics, ideal mathematics.

Thus, were right those claiming that Plato's teaching was influenced by cabbala? Not quite so...

For ages, since Plato's time, cabbala is setting forth in a new way. And on intuitive level, it necessarily develops as a common mathematical ground provided by Plato in all religions and Epistemologies. Its main principles were many times discovered in separate nominal laws, universal mathematical regularities, religious commandments.

Thus, were right those claiming that the cabbala was influenced by Plato's Teaching? Not quite so...

In this message, cabbala is given in a focus of concrete numbers that established by God, mystically predicted by Heraclitus and Pythagoras, precisely mathematically founded by Plato; those numbers which were discovered in religions and sciences of humankind long time ago, but brought to Plato's ideals by authors [1] for the first time. By this, it is undeniably demonstrated that it was exactly strict mathematical principles of cabbala that were borrowed as foundations by different religions and sciences of humankind and all the knowledge obtained [2] is just particular bright facets of the immense Entire Divine Arrangement and Understanding of the world (see table). 
Exactly so: all the sciences and religions, beginning from cabbala, are akin to Entire Understanding!

If only anywhere in the world an inquisitive Jew contemplated on an Arrangement of something in the world, he got spiritual supreme Knowledge called "cabbala"!

The aim of contemporary cabbala [3] is still immense: to transmit the knowledge of that Light of God is omnipresent. However, the practical application of cabbala is narrowed nowadays to spiritual self-perfection of Man's consciousness ethics, to the elevations of their own being until the complete merging with Divine Light. An achievement of this goal is called ווקית רמג (ghmar tikun, the end of correction, Hebrew). This means only a perfection of the ethics of the self and putting the world on hold.

Theoretically, of course, one can see an immense Progress of Humankind in the end of that target, but not more than that. All that is beyond of ethics of Man' consciousness is out of cabbala as well it is separated by the global egoism of Man! The malevolent formal logic impact of axiomatic Aristotelian method is sharply obvious here. It happened because according to cabbala, since Aristotle, Man is considered more superior, than God: God has created the world for Man! Thus, almost all the cabbala is focused on particular Man today, in particular, on his ethics of consciousness.

So, cabbala, being narrowed down, has lost true meaning of its Principles long ago, their deep revolutionary causal mathematical core. It turned into orthodox religion for the few Ordained in meaning and obscure spelling of unclear words and numbers. And those faithful believers in cabbala are dreaming that cabbala will become crystal clear Teaching for all Humankind.

But an awareness becomes more and more clear, that modern cabbala, Catholicism, Orthodoxy, Buddhism, or mathematics, physics, ITC and even cosmology created and developed on their own are not capable to unite all the Humankind. And they never will not lead to overcoming egoism, nonconfidence, evil and hatred among different folks. To the Salvation of Humankind!

Only a synergy of common efforts, knowledge and skills of

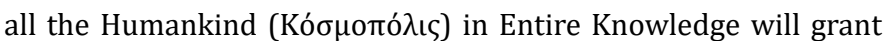
the Salvation to this world. And cabbala must contribute to that synergy!

These dreams are justified so far as cabbala possibilities are not limited by merely ethics of human consciousness! The Order, hidden in it for millennia, can enlighten many other unclear things, provide with the unexpected answers to all "antagonistic" issues to emerge. It was even Einstein (cabbalist?) who believed in one simple and true formula that can explain an entire universe. Cabbala led and leads us properly to that that crystal clear to all formula. Thus, even simple, but systematic cabbala studies are mystically and properly developing complimentary sixth sense of interconnectedness in any particular Man with Divine LightOrder (according to Plato - with World's Order) that governs the world.

In truth, it is only what has maintained in cabbala from primary-sacred-true, though, and still leads us to comprehension of its deeply hidden mathematical gist.

Yet, the main direction of that movement, the comprehension of that gist, that Cognition, - is wrong!

According to cabbalistic tradition, the beginning of that gist was given by the first spiritual leader of Humankind (and of the Jews) - by Adam, the First-person. It was given in circumlocutional ן (Razyel' Malach, Secret Angel - Hebrew). The gist was supposed to be a Universal Power (an Angel) that governs the Universe yet, it was composed of particular powers (sub-angels) that were lined up in levels. And even at that time, the gist of cabbala revealed secret mystical meaning of different religious beliefs and scientific Knowledge, that were emerging all over the world. Cabbala called for to spiritual development for the purpose of correspondence to eternal Divine laws of the universe.

The second spiritual leader of the Jewish folk was the forefather Abraham, based on the book of Adam, has written the other book in 17-16 BC, הריציה רפס (Sepher Yetsyra, The Book of Creation - Hebrew), in which not only transmitted his observations and hidden knowledge of the universe, but had specified their structure. Abraham has revealed a hierarchical system of the upper powers, he has transmitted it in more technical way, but still in the ciphered, cabbalistic language.

The third spiritual leader of the Jews was Moses, who had interpreted cabbala in book הרות (Torah, The Light - Hebrew), that had much later become the ground for worldwide famous Holy Bible. In its design, the cabbala by Moses was simple and clear to any Man who is able to see the higher world through the prism of our one. To see the special world, the spiritual one 
that governs the world, one which gives us, and other objects that surround us their birth. The simple cabbala given by Moses, with its oral transmission from generation to generation, has become cluttered with many of incomprehensibilities, however. And it is very likely that it became even more abstract, correct yet more ciphered. Those, who read Torah, have only seen an interesting narrative on terrestrial Mankind and its future. For cabbalists, though, Torah revealed an ancient wisdom on the higher spiritual world.

In such an enigmatic view, the cabbala knowledge was given to Plato who ma-naged to line them up in mathematically precise and perfect "theory of ideas", and cabbala became mathematical! Plato interpreted it in his Dialogues, though, traditionally in mystical and ciphered way as well [2]!

And at this point, the oldest and tailored for thousands of years advanced transmission of secret knowledge of cabbala was bluntly abrupted by Aristotle's self-love. He dismissed an Ideal mathematics and "eidoses"-ideals from cabbalistic teaching of Plato not being comprehended a hidden mathematical sense of it [4] and suggested to use a primitive axiomatic method of formal logic instead, that was developed (Metaphysics 982b-983a14) "in contradiction to" Plato's Teaching. It was exactly in that way man has occupied the place near God for the first time. This became a counter-revolutionary change in the main direction of the Understanding of the world, became so-called "scientifically" argued for evil egoism of the Man, separation, division of sciences, schisms in beliefs, controversies, quarrels and even wars in Religions, Understanding, and World History.

At the time of battle between Plato's and Aristotle's followers in 2nd-3rd AD, the fourth spiritual leader of the Jews - Shimon bar Yohai with co-authors have written the book רהוז (Zoar, Aureola - Hebrew). Again (after Adam, Abraham, Moses), cabbala was interpreted secretly and in ciphered way. However, it was rewritten in special language, which was modernized under the obvious influence of Plato's Teaching and emerged at the time of persecution of Gnosticism in Christianity caused by superiority of Aristotle's followers over Devoted into Plato. The mathematical meaning by Plato and enormous spiritual power of cabbala were put into into Zoar, by means of merger of elements of Gnosticism and Neoplatonism.

And they have prophetically concealed, have hidden for a long two thousand years since an epoch of spiritual Understanding of the world by Divine ideals of Plato, expressed by bright and meaningful achievements of antiquity was bluntly interrupted by epoch of folly by Aristotle [4].

Began centuries of cruelty, brutality, wildness of Medieval ages have happened.

Began a spiritual exile of Mankind from the world of Heraclitus, instead of its clear copying, repetition, modelling of the purest, Divine ideals discovered by Plato, to the ghostly world of concocted "true" axioms and "scientific" demonstrations by formal Aristotelian logic. Sacredly forecasted in the Zoar book was talking about that secret knowledge of that book will be revealed only in the end of 20th century. The most valuable Knowledge of the cabbala of the Ancients, improved by Plato, was prophetically ciphered for a long 2000 years and must be revealed at our time!

\section{Are you ready?!!}

Though, the cruelty happened to Hebrews History, in particular, the mass expulsion from the Spain in 1492, forced the 5th spiritual leader ARI (1534-1572) to create Lurian cabbala, and his interpreter Yeguda Ashlag (1886-1954), nicknamed as לעב מלוס (Baal' Sulam, The Owner of Ladder - Hebrew) to write (Sulam, Ladder - Hebrew). At the very high point of Medieval Ages (much earlier than predicted by the prophecy of Shimon) ARI suggested to Mankind how to avoid epoch of Aristotelian Folly but by a solution based on the study of the same Aristotle: in ascending improvement of man's egoism toward the God's purity (instead of affirming the constant God-likeness offered by Heraclitus and Plato). The author of this method and its interpreter has built up the entire ladder of man's countless the steps-axioms for successive ascend to the Creator, gradual feeling of His higher spiritual power (instead of clearly limited Divine ideals-numbers in terms of NeoPlatonists). It is the basic contemporary textbook on cabbala even for today, an absolutely full cabbalistic teaching and methodology of comprehension of higher world.

Yet, the direction of that methodology was dramatically wrong chosen!

It was not by chance that the authors highlighted that frequently appearing word instead. This one is one of the meanings of the Greek prefix anti-. Doing that, authors want to focus on Aristotle's "contradictions". A man with enormous faculties, knowledge and skills and who became indisputable authority for many of Mankind 
who accepted him as a Messiah (instead of Christ?). Not having the rights of state violence (he only created Alexander the Great), he became recognized as a state ruler all over the world - even children at school and all scholars of all sciences genuflect to and salute his axiomatic method and formal logic. At the place where God-the-Christ must be you all consciously placed inexhaustible Source of autophilia, egoism, sin that pretends to be God!

Please note! The main ARI direction of methodology of Understanding - from Man to God, "Man for God!" - was suggested by Aristotle instead of fundamentally "contrary" of found by Plato - from God to Man, “God for Man!". Plato has determined [1, p. 521] "an ideal, eternal, unshakable, unconditional Lawsorders, unflinching requirements and strict Rules of behavior that independent of Man and govern him" - (theocentrism) an Order of life by God that leads to ideal morality of Mankind. ARI's "ethics by Aristotle" - "was designed by Man, it cannot be alienated from his life, it lives according to axiomatic method with him and changes by Man himself" - (anthropocentrism) - it continuously leads to ideal Man. Apparently, it is also a noble purpose for life! But Mankind did not notice how subtly and cynical Aristotle rebooted Mankind, reoriented it "contrary"! He changed the main direction of Christ Cognition: he replaced Plato's theocentrism with Man's self-importance, self-love! And with disastrous consequences for Mankind!

Let us think through, at last, where the root of and main Source of our egoism, unfriendliness, dissidences - everything what is bad for Mankind - it is an axiomatic Aristotelian method!

Now, the definition of cabbala sounds insidious and hypocritical in kind of Jesuit language in Baal' Sulam: "This wisdom is a causal and efficient Order of spiritual root ascending, that is submissive to constant and absolute laws, connected to each other and aimed at one exalted point that is called "Creator's Divinity disclosure to His creatures in this world". And "wisdom", and "absolute laws", and even "Creator's Divinity" aimed at "His creatures", which, according to their manly initiative, following axiomatic method, discovered them instead of true exposure, according to God's initiative by His ideals. Do you see the difference? It is frightening in its consequences!

It is supposed that ARI and Sulam, allegedly, started to "disclose cabbala for all Adam's descendants". However, they only managed to interpret it in logically well-composed Aristotelian speculation that united Neoplatonists idealism with realism of Medieval scholastics. As a result, they postponed an understanding of enigmatic mathematical gist of cabbala since they reduced it to the motto: "The whole idea of the Creator is to create a Man, improve his personal life by means of Aristotelian egoism and by desire to get pleasure". Below follows the very ARI's teaching, strictly according to Aristotle as well (from Man to God): "In our world we have only one law - the law of absolute egoism: we have law of absolute altruism in spiritual world. Man is born not alive in terms of spirituality, the egoism takes place where God must be as long as Man, generally speaking, is feeding from devil powers. Thus, he cannot feel the Creator and can only approach Him by means of their endless axioms. And at some point, a desire is given to Man - "a point in heart". Then cabbalist, who feels the spiritual world, can see part of the Creator's light - "by means of soul" meanwhile man, who perceives only our world, is similar to blind person. A cabbalist can create a vessel ("soul") that intakes a Light of Creator. Ascending to higher spiritual stairs, created not by Man (תוריפס Sefirot 9 , or 10 , or 125 , or 620 , or 6000 , or "zillion" - "it depends on measurement"), cabbalist conceives Spiritual Laws-Qualities that emanate from as Creator's Light - this is a spiritual movement. After reforming their egoism, cabbalist becomes absolutely similar to the Creator - it comes "Mashiah" חישמ (the end of reformation Hebrew). It is impossible to achieve this last stair for no one "soul" until it merges with other "souls" in Complete Reformation".

Have you seen in such "disclosure" of cabbala by ARI and Sulam any mathematical gist? There is no clear determination even at exact quantity "Sefirot" because incomprehensible settled by God and found by Plato "eidoses"-ideals-numbers were replaced of concocted by Man (instead) "Sefirots"-stairs-axioms! That is why it is impossible to count them because there are so many "it depends on measurement" inasmuch as there are many those who count them! What to say about mathematical regularities of appearance, achievement, change of "Sefirots", emanating and intaking "Light" and their impact on "soul" of Man? Where are mathematically exact expressions of Laws-Qualities that were advocated? Aristotle-ARISulam cabbala is just point out at such "absolute laws", their strict system character and enormous influence on Man's consciousness ethics yet, it does not show any mathematical example. Mathematical gist of cabbala is still remains hidden not only "for all Adam's descendants", but also for those authors of such cabbala "disclosure"!

It was because since Shimon, cabbala had already contained improved by Plato strict mathematical knowledge, deeply 
ciphered by Plato himself and in addition, by secret concepts of ancient cabbalists. The attempt to decipher them with the help of Aristotle's approach was useless in Greece or in Egypt. How could it become useful in Israel, and especially in his exile from Spain?.

Authors of this message can not boast about mystical knowledge of Hebrew language, however, they managed to [5] decipher Plato's numeric dialectics in Dialogues. They found his ten "eidoses"-ideals-numbers and improved them until they reach ideal form, restored an Ideal mathematics of Plato and practically implemented an ideal mathematical modelling (discovered anew by researching of rolling rolls) by numerical dialectics of Plato even of contradictory manly ideas that necessarily defines the "measure", the "golden mean" - the Truth of the final results.

Thus, it is possible to notice ciphered Plato's concepts, conceive their secret meaning and explain their actual, improved by Plato and still deeply hidden mathematical gist of cabbala even when some of translations of passages of main cabbalistic books or copious interpretations into Russian are in use.

First of all, at the very beginning of Talmud there are some very eye-catching expressions [6]:

- 142 - Torah is composed of four notions (categories): 1. World; 2. Year; 3. Soul; 4. Control of World, Year, Soul.

- 143 - The World is inanimate and vegetative nature. The Soul is people and animal world. The Year is evolvement of generations from cause to the effect. The Control is ways of existence of three previous notions.

- 144 - All four categories emanate sequentially from the Creator into four worlds - Atsilut, Briah, Yetsyra, Asiya not being in change. The Creator, who puts four categories on, hides Itself. The four categories in our Asiya world are called Open Torah. And four categories in the worlds called Yetsyra, Briah, Atsylut are called cabbala".

- To sum up, according to Talmud terrestrial Man goes trough the: 4 categories $\times 4$ worlds $=16$ consecutive steps "Sefirots" before the Merger with the Creator.

Compare with Divine world of Plato ("Timaeus" 39d-41b): "It is the quantity of forms are considered to be realized in the cosmos as the same quantity of [main] forms which is considered by mind in animated, as it is. In total, there are four: celestial genus of gods is the first of them, feathered genus that soars high in the air is the second, aqueous one is the third, pedestrian and overland genus is the fourth. God created divine genus basically out of fire... When all of the gods... got their birth, the parent of the Universe appeals to them with such talk as: "Gods of gods! ... Three genera are still not born yet, you all to treat evolving alive creatures according to your nature imitating my might, by means of which your own beginning has happened".

In all, according to Plato, there are: 4 genera of gods $\times 4$ gogs of gods = 16 gods of gods ('eidoses'-ideals-numbers). God grants this as eternal examples for intellectual activity of Mankind for the sake of his Salvation!

Try to find 10 differences of Talmud by Plato! There is none! Except main general directions of Understanding - they are strictly "contrary", as it is meanly designed by Aristotle-Antichrist!

Further in cabbala one could find many other opinions on "How much do we have Sefirots?" For instance, "The four stages of the Light emanation are necessary for the very wish to enjoy that Light would be. STAGE 0 - "to create the creation according to the idea of Creator. And the creation is similar to fetus at stage 1. STAGE 2 wants to be similar to the Light. STAGE 3 wants to be similar to the Creator. STAGE 4 wants to get all the Light that emanates from the Creator".

Or: "There are 4 stages of direct Light In the head of every Partzuf. These 4 stages of direct Light are in the head and this is what we call an eyesight, hearing, smell, sense of touch. Thus, 4 stages of direct Light are merely Sefirots that are in the head of every Parzuf". Even according to Aristotle's calculations, man has five senses. Thus, the ciphered speech in cabbala tell another story here - not about senses, but on more important, on mystery!

Or: "Each creature is composed out of four bhinots of roughening in which the Light of Creator is spreading and creating a kelym in creation, and these parts in the creation are called 'hokhma', 'bhina', 'tiferet', and 'malkhut' and called 'fire', 'wind', 'water', and 'ash' as well.

Or: "The roots of four bhinots are emerging in the head, and in the Partzuf's body they will be called as four sefirots: hokhma, bhina, tiferet, malkhut. These four bhinots represent four Lights: nefesh, ruah, neshama, khaya, the general Light of which is already was called by us as yehida".

At this place, cabbala gradually approaches the next mysterious notion from Plato by means of terms such as: "soul", "vessel", a 
"middle sefira - yehida". Plato has interpreted it by means of not clear terms as well: "soul, Khora, mixture, Eros, ideal state, round dance" and other. Aristotle called them as "intermediate mathematical objects". Our research $[1,2,4,5]$ shows, that all three cabbala, Plato, and Aristotle all these mysterious terms are equally represent an ideal mathematical model that was formed by four first and the simplest "sefirots", "eidoses"-ideals-numbers, that is to

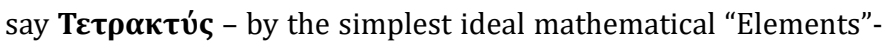
operations that form them: "Earth" is an addition; "Water" is a multiplication; "Air" is a combination, "Fire" is a involution. An ideal mathematical model is a vessel, created by Man, into which the Light of Creator enters (ideals and ideal operations).

Beautiful quotations from Talmud: "The only thing that Man can do is to create a vessel in which one can get the Light of Creator. That vessel is called "soul" and Light which it intakes at that moment is called the Light of life. Man can be included into Higher government according to the degree of how They could do that... If you have prepared vessel ("soul"), the Light enters it and at this degree you have a Merger with Creator... The "soul" must be independent in order to feel to be granted by Creator and give back, to be similar to Him. To do that, it must be moved away from the Creator as much as He could not act upon it and it Could commit absolutely independent actions... All the Zoar, all Cabbala and all Torah tell us only one thing: on how for Man to get that Light (this is where the mistake in the direction of Understanding, says Plato: as God produces that Light!)". All the universe was created for that purpose where Man created at its lowest point could elevate at the highest and to explain to him how to manage it... It is impossible to achieve the last stair of merger with Creator for none "soul" until it merges with other "souls" and until they reach full recovery... The "soul" is absolutely different from what our meat is. Today it could be one thing, tomorrow - another: part of one and part of the other and so on. It is not constant construction... The circulation of "souls" is continuous, constant process, indeed. Man creates this mechanism on Their own within himself starting from zero. They on their own create a system of the worlds within themselves... Cabbala is what Man feels within as manifestation of Creator. When he can clearly turn definite qualities in himself by means of those instructions, can tune himself, go further and further and further! That is to say, each higher world produces consequent with a definite feature such as kelym, and not in quantity, but in quality".

By these (in brackets below) magnificent words, in their beauty close to Plato's poetry, and in their meaning exactly quoting secret mathematical meaning of Plato's Teaching, cabbala teaches Man an ideal mathematical modelling (gives instruction). One needs to take an ideal (accept the Light of Creator) and, according to His eternal pattern, build up (on your own) your contradictory ideas in ideal mathematical model (to create a vessel). To solve the model by means of ideal mathematical operations and always reach certainly correct results (a manifestation of Creator, the Light of life). Not to concoct "true" axioms and "scientifically" adjust to them your own creativity (Man for God?), but relying only on created by God eternal ideals and get the Truth such as: God for Man! According to Plato, it is only by means of such ideal mathematical modelling all the Universe has been built up by God; (Man can be included into Higher government starting from zero, builds up a system of the worlds within himself - and, according to Aristotle, Insted). "Contrary", again?!!!

Yet, the full Merger with Creator is possible only after the merger of all the "souls" altogether - when all the Mankind will learn together to do only ideal mathematical modelling. "In order not to fabricate any spirits or certain angels, shadows on the wall. We do not have that here. We have in hand what we have. And what we do not have, we do not have. Thus, cabbala is called a science and not mysticism". Do you notice Aristotelian empiricism and how he criticizes Plato in his hint to "cave-like" (shadows on the wall) mathematical modelling, blamed by Plato in his "Republic", yet, exalted by Aristotle until axiomatic method in "Metaphysics"?

Cabbala after Plato is an anthem to ideal mathematical modelling! However, did you hear it from famous "cabbalists: rabbi Shimon, ARI, Ramkhal, Agra, Baal Shem Tov, Ashlag?”.

The first in this list Shimon became the last one, who knew that anthem. These were his words, highlighted by us as "beautiful and magnificent" were remained somewhere in Zoar, Torah, Talmud texts, and even in their countless interpretations. But the secret Plato's mathematical meaning of these "magnificent" words was long tie ago forgotten, oh! - even worse: it was polluted by harmful Aristotelian extraneous features when it is practically impossible to look at through them. However, armed with knowledge $[1,2,4,5]$ in numerical dialectics, Ideal mathematics and Plato's real ideals, it will be possible to easily identify and identify the true right goals and spiritual direction of the modern knowledge of cabbala.

Encrypted Teaching passed to the Gnostics and Neo-Platonist, who placed it in the foundation of the Christian Church and further more encrypted. Additional keys are religious. 
Christianity arose undoubtedly the influence of cabbala and of the Teaching of Plato. But the Teaching was deeply ciphered by its author. Therefore, in the theology of Christianity, the various versions of his interpretations constantly arise and arise, and a struggle (even wars) for the canon of the "path to Salvation", the true version of which is unknown to anyone or is still carefully hidden by someone. The agreement establishes on the Ecumenical Councils. The subject of disputes is the Divinity of the Trinity and its influence on Mankind.

Cantor noticed that the Aristotle's potential numberlessness, forming the series of natural numbers, is simultaneously the simplest actual infinity of Plato. According to Plato, this order of priority of quantities guarantees only by a primitive understanding. He also noted the infinite possibility of forming new actual infinities but did not investigate themю. Tried to present ideals with "transfinite quantitative numbers" but came to contradictory paradoxes. Refusing to consider the order in the new sets, he limited himself only to the representation of their quantitative power by the infinite "Tower of Babel". The unexplored by Cantor subsequent actual infinitys with their more complicated connections between the elements of sets form new numbers (whole, rational, real,...) model new qualities, than each provides new intelligence for the progressing human reason, since they are the desired ideals of Plato, each with the Universal God Minds and the criteria of the Absolute Truth. That is, Cantor stopped, literally, a step from the reasonable ideal numbers of Plato and did not open them.

The formal logic of Aristotle already two thousand years tries to replace the Divine orders of ideals with human axioms, but inevitably overcomes the «insoluble» Problems and only approaches the Truth. To achieve happiness in this way - is unreal!

There are endless debates around the esoteric Teaching of Plato, its content and even the place where it should be sought. The wave of opinions caused by the "Tübingen revolution" has not yet abated.

The authors together with Plato further generalized the order of precedence of quantities by the multistage addition of units, found the universal mathematical order and built ideals of the Ideal mathematics of Plato - the World Mind of God. Ideal mathematics is fills the logical omissions of conventional mathematics, generalizes numerous duplications, makes Knowledge simple and understandable. Such mathematics are easy to learn, apply and develop further.
Our with Plato the study confirms the correctness of Schleiermacher - the whole of the Teaching of Plato is stated in his "Dialogues", but for deciphering requires unusual keys - mystically mathematical.

The authors together with Plato for the first time proposed to understand the numerical dialectics of Plato by the ideal mathematical modeling of Kljujkovs. And represent the incomprehensible fanatical symbols and dogmas of religions, who blindly tear Mankind, by numerical categories - reasonable, clearly realized, which will unite all. The mystical categories of the dialogues of Plato "Laws" and other are compared (-) with the incarnations of the Holy Trinity at the Bible and suddenly are given (:) by deciphered mathematical representations. "Good", "World Mind" - God the Father: this is the ideal mathematics of Plato. "Chora" - God the Son, Christ, the mediator between God the Father and the peoples of the world: is the ideal mathematical model, Plato's mediator between the ideals and the real worlds. "Salvation" - God the Holy Spirit, the Kingdom of Heaven, Salvation: is the ideal mathematical modeling, Cognition of the world by only a numerical dialectic.

Such representation will become the basis of the Unity of Sciences and religions, will become the ingot of the Divine and the human in the common religion of Mind for all.

The One Cognition predicted by Heraclitus, created by Plato, was torn by Aristotle into many separate sciences, religions and metaphysics. Now us with the Plato stubbornly propose to restore again the reasonable, mathematical, scientific, religious, mystical and Unified Cognition.

The authors together with Plato for the first time openly suggested disclosing the mystery of cabbala by mathematical essence. Mathematical cabbala is already the basis of all the sciences and religions of the world, and in the future - will unite them into the One (by Heraclitus) Scientific Cognition by all means with mystical properties and the ideal morality of the One Intellectual religion of Mind.

Replacing the analyzing axiomatic method of "matter and forms" of Aristotle by the numerical dialectical method of "ideas and ideals" of Plato, the authors propose mathematical Thomism and Teiardism, which unite two powerful sources of Knowledge: the scientific Cognition of Nature and the religious Cognition of God. With the goal of the formation of a universal religion of the Reason 
in the whole world without disagreements and confrontations - in complete harmony and divine Salvation of Mankind.

Such a cardinal change in Cognition will always and all lead to the Truth of any question. The causes for quarrels, strife, splits, wars will disappear - who will go against the Truth?! The era of happiness will come!

But the change do not perceive confronted by individual scientists, scientific journals, societies, even national Academies of Sciences and World Churches - they are afraid of becoming a "black sheep" in the present world of a tough confrontation and of uncompromising struggle of all against all, for the sake of survival. The Our Efforts and Plato are clearly not enough for the nearest universal enlightenment and happiness of the peoples of the world, for the Salvation of this world.

All strictly, according to Aristotle, actively carry out the current direction of the Cognition "Man for God" - to perfect the man himself to the ideal Man. This, as well as "combating threats to peace and suppressing aggression" is trying to eradicate Evil and Injustice all over the world. But you can do this endlessly and never achieve the true result, as it is impossible to create or educate an ideal Man!

We with Heraclitus, Pythagoras, Socrates and Plato propose to change Cognition absolutely "contrary" to Aristotle, in the direction - "God for Man" - to perfect the morality of Man to an ideal morality. This can be understood and realized, since an ideal morality exists always and everywhere, it is eternal, unchanging and is ingeniously simply was discovered by Plato. Observance of ideal morality is also not difficult. It is a mathematical God-likeness, constant always and in all the repetition of God, duplication, copying of its ideals, the desire to reproduce them exactly as God, and to join his Truth - $\mu$ í $\mu$ í ideal morality - will become forever true. Better impossible it is to create, because in the basis of them there is always some Part of the World Mind of God.

\section{And who is wiser than him?!!}

Cabbala by ideal mathematical modelling by Plato will definitely "be revealed for all the descendants of Adam", will explain an Understanding of the Universe and for a significant Reordering of the egoistic Mankind. Mathematical cabbala is already a basis for all the sciences and religions of the world and in the future it will certainly unite them in One Scientific Knowledge with mystical features and ideal ethics of One Intellectual Religion of the world.

And its Salvation will come!

Already today, aspire to the Good of Plato only by its ideal mathematical modeling, build all your mathematical models only as ideal Plato's Chorases only by the samples of Divine Ideals (http://files.rsdn.org/20047/ideal1.pdf), and your morality will become ideal. This is the desired "useful, true, eternal", the order of together living, intuitively worked out by the population of

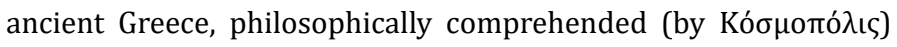
by Heraclitus, Pythagoras, Socrates, mathematically grounded by Plato and digitized by the authors - the World Mind of God.

The salvation of the world will necessarily come, as soon as the experience of such ideal behavior embraces the majority of

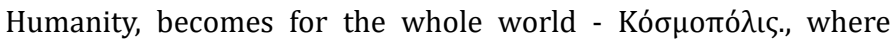
people "with the mind" of Heraclitus, firmly resting on the Divine "World Mind" of Plato, will easily build the Unified Cognition of all Sciences and Religions by the "reasonable" numbers of the authors, will become virtuously "observant of the universal Logos" and, forever deprived of the inhuman Arrogance of Aristotle's and "of all behind him". Become, at last, Humans-Gods! And organize on an equal footing the present community with the Gods - the practical

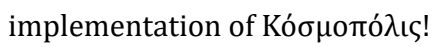

Saving the world and happiness for all will surely come, as soon as the experience of such ideal behavior encompasses the majority

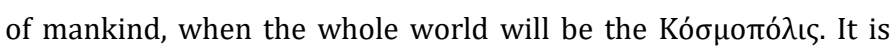
necessary to return to Athens the mathematical doctrine of Plato. Plato bequeathed ("Laws", XII 968a-969c) to glorify "perfect guardians for the protection of Virtues that we have not seen in our former life... on the Acropolis, towering over whole the country (world?)". Let it be a well-deserved mathematical monument - the "Stele of the Mind of God" (Figure) - 16 "eidos" - ideals-numbers of Plato. In the implementation of the option, the authors are ready to invest their "five kopecks", as a gift from the Mariupol Greeks.

If in Athens will be reborn a process, that likens God by the ideal mathematics of Plato, this become will be the true Salvation

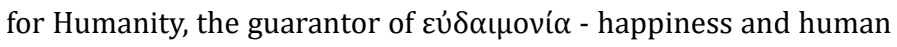
development.

We appeal to you for support and assistance. Help implement! We are ready to cooperate as experts, volunteers, unskilled workers of the One World Mind of God. 


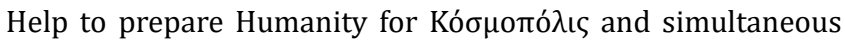
for the constant mathematical God-likeness offered by Heraclitus World mind of god and Plato in the version that we digitized. This will benefit all of Humanity, including you.

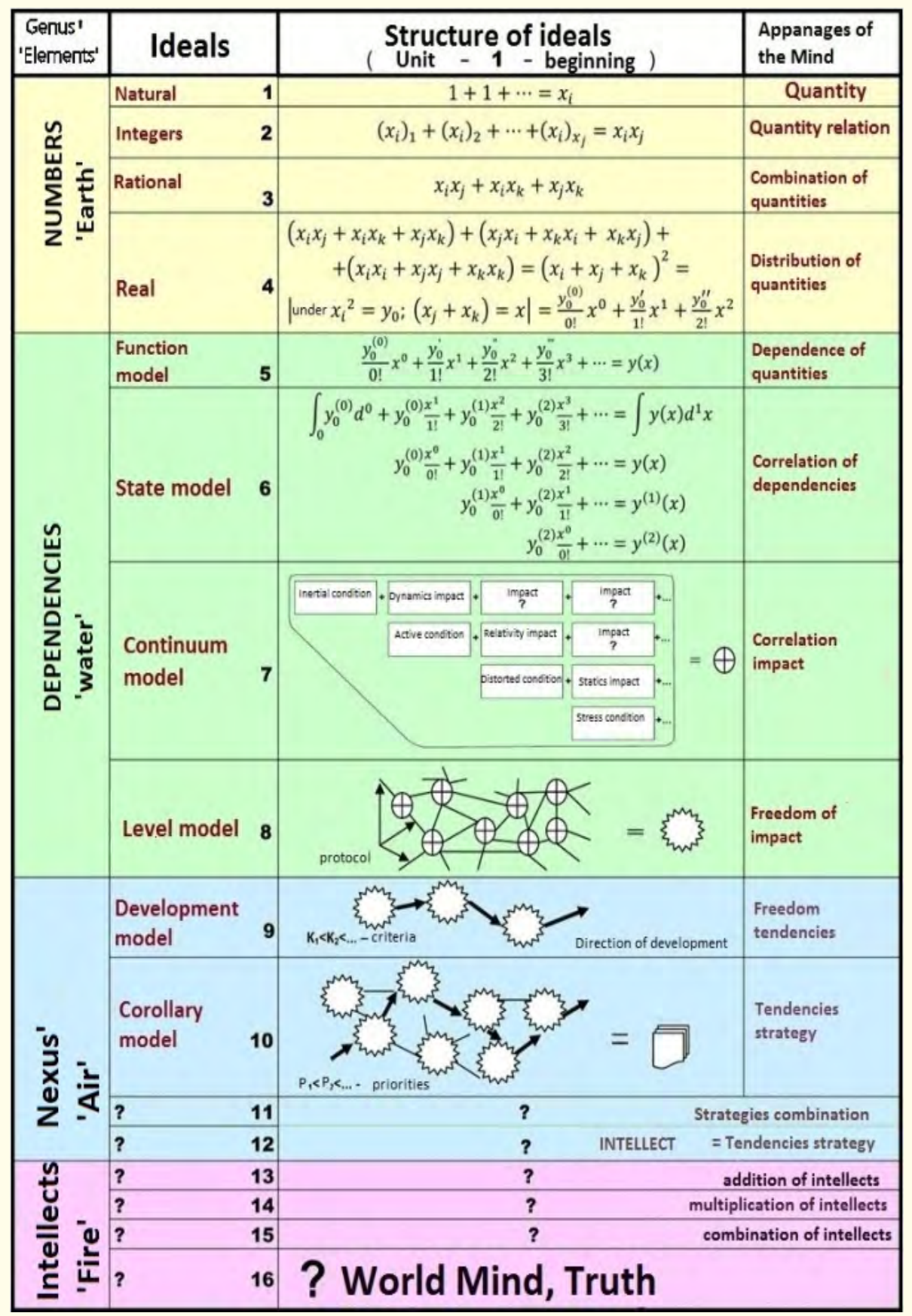

Figure 


\section{Bibliography}

1. Клюйков СФ. Идеалы. Книги. Мариуполь: Типография «Новый мир», (2009): 672с.

2. Клюйков РС., Клюйков С. Ф. Правда о Платоне. Книга восемнадцатая (Учебник 18 лекций). - Мариуполь: 000 «ППНС», (2017): 300.

3. Берг Й. Каббала. Сила изменит всё. - М. : «Эксмо» (2010): 224.

4. Kljujkov R.S. Kljujkov S.F. Aristotelian curse. Book fourteenth [Prokljatie Aristotelja. Kniga chetyrnadcataja] - London: Published by IASHE (2016): 174 .

5. Kljujkov RS and Kljujkov SF. Ideal'naja matematika Platona. Kniga desjataja. Saarbrucken: LAP LAMBERT, (2013): 134.

6. Лайтман М. Учение десяти сфирот. М.: НПФ «Древо Жизни», (2003): 640.

Volume 3 Issue 7 July 2019

(C) All rights are reserved by Roman Kljujkov and Sergey Kljujkov. 